\title{
EQUiLIBRIUM
}

Quarterly Journal of Economics and Economic Policy

2015 VOLUME 10 ISSUE 3, September

p-ISSN 1689-765X, e-ISSN 2353-3293

www.economic-policy.pl

Sipos. Á. (2015). Shared State Taxes and Tax Policy of Local Self-governments in Connection With Tax Morale. Equilibrium. Quarterly Journal of Economics and Economic Policy, 10(3), pp. 65-88, DOI: http://dx.doi.org/10.12775/ EQUIL.2015.025

Ágnes Sipos*

Budapest Business School

College of Finance and Accounting, Hungary

\section{Shared State Taxes and Tax Policy of Local Self-governments in Connection With Tax Morale M* $^{* *}$}

JEL Classification: $H 21 ; H 23 ; H 24 ; H 26$

Keywords: tax morale; legal morale; tax regime; tax system

\begin{abstract}
Based on our assumption, tax morale significantly depends on a country's legal, historical, social and cultural background and circumstances.

In the first part of the paper, we discuss the legal dimension of the tax morale - including the interconnection of law, ethics and moral. Furthermore, we analyze the facts breaching tax liabilities under the scope of the criminal law and the actions violating the tax morale but not qualified as infringement of the criminal law. In the second part of the paper, we provide empirical evidence on which factors (e.g. personal characteristics, commitment for paying local taxes, knowledge about the distribution of paid taxes between central and local authorities, etc.) determine significantly the individual level of tax morale.

The paper discusses these complex connections either from the viewpoint of law or economics in order to find out whether it is possible to develop the tax morale of individuals, or can the legislator adequately rule the different forms of tax evasion.
\end{abstract}

(c) Copyright Institute of Economic Research \& Polish Economic Society Branch in Toruń Date of submission: April 8, 2015; date of acceptance: June 12, 2015

* Contact: sipos.agnes@kkk.bgf.hu, Budapest Business School, College of Finance and Accounting, 1149 Budapest, Buzogány u. 10-12, Hungary 


\section{Introduction}

In this paper there are three equally important purposes: (1) to define "tax morale"; (2) to give an overview about the changes in the proportion of shared state taxes (personal income tax [PIT] and vehicle tax) between state and local budget since the change of regime; (3) to present the Hungarian tax morale with some actual data and to give empirical evidence in connection with individual tax morale.

My intention was that besides historical and social circumstances other factors - such as Machiavellian personality, commitment and faith to state and local government - also have a very significant impact on the level of the individual tax morale.

\section{Shared State Taxes and Local Business \\ Taxes - Declining Share of Local Governments in the Hungarian Tax System}

The state has the sole right to specify and allocate state taxes, and has the right to give power for local governments to lay down the rules of local business taxes, and the state furthermore has the right to monitor the activity of local governments. So the taxing power of local governments is derived and limited by the state.

Accepting the importance and role of taxation at level of local government, several alternatives may be distinguished depending on who should tax, what the shares of tax revenue are, etc. Local governments may derive revenue from local taxation by any of the following (Davey-Péteri, 2004, p. 217.):

- Laying taxes independently;

- Imposing a locally decided surcharge on a revenue laid and collected by other levels of government;

- Receiving a fixed share of state taxes collected within their jurisdiction. Different models can be mentioned to analyse the fiscal connection between state budget and local government budget. On the one hand, we can mention a model where all incomes of local government rise from the state. In this model only the central state tax system exists, there are no possibilities for local governments to lay down the rules of local business taxes, as they have no taxing power. A disadvantage of this model can be that local government is naked, but an advantage can be a better monitoring regime of state tax system, as the state is able to monitor more efficiently the way of incomes in the case of local governments too. 
The second model is the solidarity model, where the local government has taxing power, has the right to lay down the rules of taxation, but some taxes are centralized by the state budget, where the state has the sole right to decide the share of local governments for the tax incomes. One advantage of this model is that structural differences can be lower in this way, but a disadvantage is that governments - cardinally the rich governments (they have enough income from other sources)- are not interested in increasing their incomes as a certain share will be the income of state budget.

The third model, liberal model, where local governments are free to lay down the rules of taxation, the state has no right to centralise tax incomes from the local government, and the main incomes are the local business taxes for the local governments. The fiscal responsibility of local government is the greatest in this model, but one risk of this system can be a conflict between the fiscal interest and economic policy of local and state authorities.

In Hungary, there is a mixed model, where the characteristics of liberal and solidarity model are combined, certain taxes are incomes of state budget, and then the decision is for the state to allocate the tax income between the level of central and local budget. The cooperation and harmony is realised between the levels, the local governments has taxing power and besides they gain tax incomes from state budget as well (the so-called shared state taxes).

Hungary has been a pioneer in local government reform among transition economies. Through a series of legal reforms introduced since 1990, Hungary has established local governments with full autonomy, legal and regulatory framework for ensuring and tightened budget constraints by regulating municipal bankruptcy. So in Hungary after the change of regime this mixed model is used, but the borders of the framework are continuously being modified by the state.

Increase or decrease in the autonomy of local government was the twodirectional tendency since the change of regime by the state. This tendency has an effect on fulfilling task and on fiscal frame too.

As an example of this tendency, we can mention the allocation of personal income tax (PIT) and vehicle tax. When personal income tax was introduced in 1987, the allocation of this tax income was very simple: it was the income of the so-called "tanács" (the forebear of local government). In 1990 there was a claim to change this allocation structure, the state had to decide two issues:

- How to allocate personal income tax between state and local government budget? 
- Will it be still the income of the local government, or shall we introduce a quota, guarantee sufficient income for the state and local government too?

The Budget Act of 1991 (Act CIV. of 1990 on the State Budget of Hungary) introduced a different allocation system in the Hungarian Law. In 1991 the local government received the income raise from paid personal income tax by local taxable person in 1989 .

In my opinion, local governments are able to levy taxes on unseen income and to collect these revenues in greater proportion in general, because of e.g. the local relationships are generally tighter.

In the 90's, the proportion of shared state taxes decreased. In 1993 the local governments received the $30 \%$ of PIT, while in 1998 only $20 \%$ of PIT was returned to local level. Since 2000 this proportion of local government was permanently below $10 \%$. Since 2013 the local governments has not receive a certain percentage of PIT as earlier, only the revenue comes from the leasing of soil remains at local level.

At the beginning, the vehicle tax was also a shared state tax, which was collected within the jurisdiction of local governments, and was the revenue of local budget. In the 90's there were different shares between local and state budget $(100-0 \%, 50-50 \%)$. In 2015 the revenue from vehicle tax is divided between local and state budget as follows: state budget has a proportion $60 \%$, local government's share is $40 \%$.

\section{Local taxes in Hungary}

In Hungary the 1990 Law on Local Taxes declares the possible types of local taxes local governments may levy, maximum size of local tax rate is also set centrally. Local governments are entitled to introduce any or all of the following taxes: property tax, communal tax, tourism tax and business tax.

Property tax can be imposed on residential and non-residential buildings and plots. Local governments may decide free whether the assessment of tax burden will be area-based or value based. A value-based property tax is applied only by a few local authorities recently. Communal tax is levied on private residents, it is a special property tax, since it can be levied on household dwellings (owned or rented).

Tourism tax is one of the most conventional local taxes in Hungary, it can be levied based on turnover (per capita accommodation fee). 
The business $\operatorname{tax}^{l}$ is a turnover tax levied on manufacturer's and retail sales' net turnover.

\section{What is Tax Morale - How Can We Measure Tax Morale?}

For the question how can we define tax morale, it is impossible to give an exact answer, even if we know the diversified specialized literature. To get closer to the definition of tax morale at first we have to define ethic and morale. Ethics is a main form of social norms, a collection of accepted norms which had been accepted during more and more generations and which are synthesized on the base of common observations. In other words, it is a community's judgment about what is right and what is wrong, helping to differentiate between good and evil in the society. ${ }^{2}$ The word morale comes from Latin "mos", principally meaning "will" in its objective sense, which manifests itself in ethic and in the law. In another sense, it also means the will, approach and grain of the individual, of course strongly connected with habit, ethics and law.

In the specialized literature firstly Frey-Weck-Hannemann (1984) defined tax morale ${ }^{3}$ in 1984. Nowadays several publications are concerned with the question of tax morale. ${ }^{4}$ Földes (2004) defined tax morale as a zero-sum game of dividing the contribution to the total public good between the members of society (which means particularly that any fraud on tax by one member of society cause a loss to another one).

Méder et al. (2012) define the basic problem of taxation as follows: “... there is no tax paying instinct". The question of paying or not paying taxes is relatively new in our history and in this sense it differs from the other forms of cooperation in more ways. The significant problem of making people paying taxes: the individual is unable to punish the cheaters effi-

\footnotetext{
${ }^{1}$ Business tax has a dominant place in the Hungarian local tax system, it constitutes more than $80 \%$ from total local tax incomes of local governments.

${ }^{2}$ Laws and bills are in connection with ethic. Morality and legality are connected, but they are not the same. Ethic concerns people in their deepest nature, will and conscience, it is in the inside personality, which cannot be judged by court. Legality means the responsibility of law (Turay, 2000).

${ }^{3}$ Tax evasion is usually explained by the Laffer curve, which shows income from taxes as a function of marginal tax rate. Frey-Weck-Hannemann (1984) states that tax morale is as much important as tax rate concerning tax revenue.

${ }^{4}$ Tax morale is a complex phenomenon, it concerns law, macroeconomics, behavioural economics, sociology, etc.
} 
ciently. The isolated individual would be only able to punish the cheater if he himself didn't pay tax.

Although the definition of tax morale has been used by several authors, we can say that there is no universally accepted definition. Shadowing the situation, we can say that the interpretation of more, strongly related definitions (hidden economy, informal economy, 'grey' economy, informal working) are disputed and can be divided into more branches. This is also the case for the dominant and significant factors of informal work. We can distinguish two main branches in the literature: according to the first, the rational estimation on the relative gain from tax fraud is the decisive (see Slemrod-Yitzhaki, 2002). The other considers the role of tax morale as a prior (see Torgler, 2003).

Earlier research by Allingham-Sandmo (1972) and Yitzhaki (1974) consider tax evasion as gambling. They examined how much of the income is declared by people who avoid paying taxes at a given probability of tax evasion and at a given rate of punishment. Hungarian research were initiated after the regime change in this area ${ }^{5}$. The main courses of the research were hidden economy, norm following behaviour and the new tax system developed by the changing economic system ${ }^{6}$. A study from 2004 analyzes the tax obedience and the informal economy among 900 medium and large sized companies processing in light industry, building industry and trade (300 companies in each sector) for the years of 1996, 1998 and 2001 (Semjén, 2004).

We can say that the number of specialized literatures studying the measurement of tax morale is significant, too. Among these, we can highlight the research of the Hungarian Central Bank. According to this examination of income tax declarations and VAT payments, they conclude that the amount of rateable value lost due to tax evasion equals about onequarter or one-third of the Hungarian annual GDP. This is considered a significant loss in international aspect, too ${ }^{7}$.

Some research considers the tendency of the number of enforcements in taxation as a tool of measuring tax morale. According to this, tax morale has been declined. Nowadays in Hungary approximately more than 360000 enforcements are still in process. Furthermore, debts in connection with

\footnotetext{
${ }^{5}$ However we should also mention the name of Schmidt, who had examined tax payers' behaviour and the causes in the 1940's.

${ }^{6}$ We can mention the paper by Gergely (1998).

7 http://www.mnb.hu/Root/Dokumentumtar/MNB/Kiadvanyok/mnbhu_mnbtanulman yok/MT_65.pdf, page 4.
} 
enforcements were up to a thousand billion forints till the end of July, $2013^{8}$.

The third possible aspect of examining tax morale is comparing the nonor just partly tax-paying self-employed people with the employees in the same scope of activity. Among the employed people $14 \%$ are selfemployed (individual entrepreneurs). They deny the plus burden of taxation and pay significantly less than the normal employees 9

Fazekas et al. (2010) searched for the answer to the following question in their study ${ }^{10}$ : to which degree does the rate of rational estimation and tax morale play a role in informal working in Hungary?

In case of examining the tax morale the implementation of game theory (running ultimatum, dictator or trust games) become more frequent. The empirical observations verify that tax morale plays an important role in tax evasion, because the moral behaviour of individuals is typically not independent from the behaviour of reference groups (see Méder, 2012; Simonovits, 2010).

\section{The Historical and Socio-cultural Determination of Tax Morale}

According to our assumption, today's low Hungarian tax morale is caused by our history and socio culture. If we take a look at the first half of the $20^{\text {th }}$ century, we can see the deep impression of tax evasion in society. A sentence by the attorney-general from the novel Rokonok by Móricz written in the beginning of $20^{\text {th }}$ century: "In Hungary there is one significant problem, one huge problem: In Hungary people don't like to pay taxes... Nobody likes... neither me." We can see that the situation after a hundred years is the same. People think of taxation in a negative way. They don't consider this as a contribution to social welfare, but as a distraction, for which they don't receive a reward as a return. Moreover, some segments of society draw off from paying taxes totally, and put the burden on the trustworthy tax payers.

In the historical part of this study we consider the acts of economic policy only after World War II. In the next paragraphs we will examine in what

\footnotetext{
${ }^{8}$ http://vallalkozoi.negyed.hu/vnegyed/20130903-romokban-az-adomoral.html

${ }^{9}$ http://blog.ucmsgroup.hu/az-adovaltozasok-hatasa-az-adomoral-tekinteteben/

${ }^{10}$ The study is based upon a representative sample from 2008. According to their result the high probability of being caught decreases the probability of informal working; but the fear of unemployment increases this rate. The level of tax morale is in indirect relation with the unemployment rate.
} 
kind of system the Hungarian taxation worked during the years of socialism and what effect it had on the morality of tax-system after changing the regime.

\section{The effects of socialist economic policy on tax morale}

Before the regime change the tax of state corporations were calculated on the bases of their centrally determined profit. The tax rates were usually progressive and if the profit of corporations had exceeded the centrally defined amount than tax rates could have been up to a $100 \%$. With this act the system broke down the effort to improve the efficiency of corporations. Moreover, profitable corporations couldn't keep their plus to make investments or pay dividend. If the state had found that the profit exceeded the given limit they could have taken this money away immediately.

Besides corporations the income of individuals were taken into consideration, too. During the years of socialism in Hungary personal income was classified into two groups. On the one hand, the salary income of employees, on the other hand the income of entrepreneurs and passive income such as interest, rental and dividend. While in the first category the tax burden was low, the others suffered from high tax rates.

Progressive taxation - similarly to the regulation of corporate tax decreased the willingness of entrepreneurship and people tended to hide their income from these kinds of activities. In this system the suppression of business income became a typical attitude in Hungary.

\section{Taxation and tax morale after the regime change}

In the late 80 's - short before the political change - the economy of Hungary had been radically changed. Most of all taxation was altered and re-developed on OECD practices. Market economy renewed the opportunity for people to develop new entrepreneurships and according to this, taxation on income had also been changed. After the change, both companies and individuals still had to pay their taxes in a progressive way, but there was a significant fall in the tax rates. In case of corporations before the change, the rates were about 50-60\%, by 1995 they were dropped to $36 \%$. In case of individuals the marginal tax rates fell to $50 \%$.

Contrary to the taxation in the years of socialism, after the regime change the mechanism of self-assessment became a priority. In case of selfassessment, the tax payer counts, declares and pays their tax on their own it is a kind of voluntary way which still exists in this form up till today. If we consider that before the regime change both corporations and individu- 
als had huge tax rates on extra profit, they were interested in the suppression of their income. At the same time with the reformation of taxationsystem and the significant drop of tax rates, tax payers couldn't immediately accommodate to the new system, they couldn't get rid of their habits and past experiences. In Kornai's (1990) opinion it is basically a failure to build the taxation on self-assessment among these conditions. In this environment self-assessment does not produce the real value of income tax and the state (tax authority) has to find additional information (e.g. enrichment inspect or notice from envy neighbours, etc). Finally Kornai states ironically that in Hungary, where the system is based on self-assessment, a single tax supervisor should be needed in every household, to supervise the flow of everyday income. As a solution, Kornai insists on introducing impersonal taxes.

In Musgrave's (1989) works we can find a reference on the separation of personal and impersonal taxes. It states that personal taxes are those taxes which are determined on the basis of solvency of the tax payer. Contrary to this, impersonal taxes are those ones at which we don't examine the character of the tax payer. Impersonal tax is like value added tax that does not consider how solvent the tax payer is (in Hungary we know it as general purchase tax, which is the VAT in international sense), as everyone pays it by the same rate independently from how much he could pay. Moreover we consider wealth tax as an impersonal tax, which neither considers the character of the tax payer. As an impersonal tax Kornai suggested on implementing VAT at one single rate. Contrary to this, after the regime change, Hungarian tax-system relied significantly on the personal income taxes. In $199531 \%$ of the state tax revenues were corporate tax and income tax (see Figure 1) which shows only a minimal change compared to the data of 1986.

The society could not get rid of its previously fixed norms and behaviours in the first decade after the regime change and we couldn't see improvement in tax morale (Kornai, 1996). 
Figure 1. The distribution of Hungarian tax and custom revenues in 1995

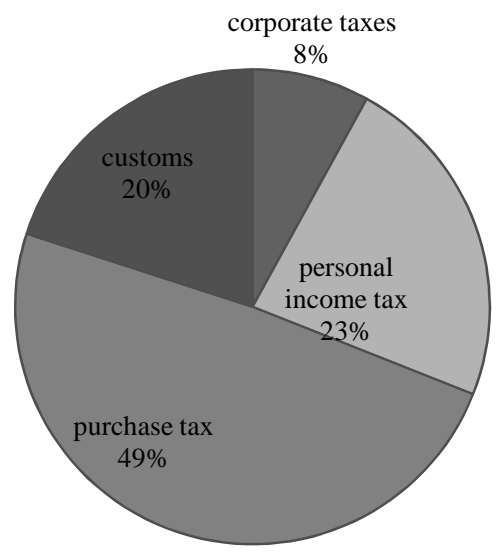

Source: Hungarian Court of Auditors.

\section{Suggestions on Improving Tax Morale}

\section{International experiences}

It is not proven that a simple decrease of high tax rates would result in the increase of willingness to pay tax and in the raise of tax base in the short term. Although several empirical studies found positive relationship between tax burden and grey economy (e.g. Schneider, 2005), it cannot be concluded generally that decreasing the tax burden is not enough to decrease the size of informal economy, and just because of lowering tax rates tax morale won't increase ${ }^{11}$. So if tax evasion is widespread, decreasing tax rates would not mean enough inspiration, even if tax evasion was inspired by high taxes earlier. Besides this, the connection between high taxes and tax evasion is endogenous, which means that tax rates are high as a result of widespread informal economy. Andreoni et al. (1998) introduced softer definitions in connection with tax evasion like ethic emotions and the satisfaction of taxpayers with the public utilities. The authors made three im-

\footnotetext{
${ }^{11}$ Scharle Ágota (2002), Tax evasion as innovation in small businesses in Hungary, manuscript
} 
portant observations concerning tax morale ${ }^{12}: 1$. more honest citizens declare more tax; 2. tax evasion is more widespread if citizens consider taxation unfair; 3. tax evasion is more widespread if taxpayers are not satisfied with public utilities.

The effect of the structure of taxes and the focus of supervision can be both significant. On the one hand, in countries where the rate of employees working in informal economy is significant, the tax on capital income is lower, which directly inspires the suppress of informal work. On the other hand according to OECD (2004), the problem of suppressed incomes is significantly lower in countries where the emphasis is on the determination of corporate income instead of supervising the amount of work.

The "continuous tax reform", which means changing the rules of taxation from year to year, makes an unpredictable economic environment and has a negative effect on tax morale. Closing those gaps which cause huge amount of loss in income and making administrative rules in taxation against tax evasion do not equal with tax reform. Making regulations that increase the will of taxpaying and decrease tax evasion in the short term does not necessarily mean the increase of tax morale in the long term, because getting acquainted with the new laws and finding new gaps tax evasion may grow again. Tax amnesties can also be easily included in expectations, decreasing further the tax morale.

When transforming the taxation system and considering its effect on tax morale and on horizontal or vertical equality, we have to take into account not only the personal income taxes but the social insurances as well. Moreover in many cases the social insurance systems mean the decisive factor. This is true even if we consider that there is a direct insurance service in connection with the social insurance taxes, which service, in case of pension and health insurance, is proportional with the paid taxes. A good example for this is the effect of the last decade's single rate tax reforms on economy and tax morale, where differences were explained by the different transformation of social insurance systems and taxes (Keen et al. 2006).

In the opinion of OECD experts the citizens responses reveal socioeconomic and institutional factors that may influence tax morale. (OECD, 2013)

The World Values Survey gives data to help build a better picture of tax morale. The OECD used data from WVS, which covered around 90 countries $^{13}$.

${ }^{12}$ http://epa.oszk.hu/00000/00017/00171/pdf/01_simonovits.pdf, 484.o.

${ }^{13}$ Hungary was not involved in the survey, for Eastern Europe Bulgaria, Moldova, Poland, Romania, Russia, Serbia, Slovenia, Ukraine was involved. 
Some very interesting observations can be found in this paper, like: "Individuals are more likely to perceive tax obligations more favourably when their government is seen to be acting in a trustworthy manner". (OECD, 2013. p. 7.)

When state strengthens and clarifies the links between revenue and expenditure it can help to improve tax more of society. Increase the transparency of tax policy making, increase the number of tax administration procedures: these measures would reduce opportunities for corruption and the willingness the cheat with tax revenues.

\section{Hungarian deliberations and initiations}

According to Kornai's (1990) thoughts Hungarian tax policy should be based on impersonal tax elements. Besides sales tax (which has even reached record level within the EU), we should improve wealth tax. This aspect is in line with OECD's suggestions. The income from wealth taxes in OECD countries makes up for the $2 \%$ of GDP. For Hungary it was only $1 \%$ in 2008 . In this sense, the attempt to introduce property tax in $2009^{14}$ wasn't groundless, although it was annulled by the constitutional court in 2010. In its regulation, the court stated that the tax in itself wasn't against the constitution, yet the method of calculating the rateable value was inappropriate $^{15}$.

Suggestions of experts of National Bank to improve taxation and tax morale in Hungary ${ }^{16}$

The tax burden on employees and self-employed has to be equalled. It decreases the attempt to show incomes from work as incomes of entrepreneur activity. Moreover, it allows for decreasing the burden of work and increases horizontal equality, which can raise the justice of taxation and increase the tax morale.

Improving trust toward the system of pension. Superannuation tax, in theory, opposite to taxes means that we will have as much pension in the future as much money we had paid, so paying this can be considered as an inevitable saving which secures subsistence in old age. Avoiding paying

${ }^{14}$ The Hungarian Parliament accepted the law on the taxation of high value assets on the $29^{\text {th }}$ of June, 2009.

${ }^{15} 8 / 2010$. (I.28.) regulation by the constitutional court: http://public.mkab.hu/dev/don't esek.nsf/0/4B835332BADF8C9DC1257ADA00528EA1? Open Document

16 http://www.mnb.hu/Root/Dokumentumtar/MNB/Kiadvanyok/mnbhu_mnbtanulman yok/MT_65.pdf 
superannuation tax can have more causes. On the one hand, it can be motivated by the discredit in the system of pension. People may think that they can take care about their own savings in a better way and these liquid savings act also as a security till then.

Increasing local incomes from taxes. In theory, those payments which are in relation with local services can be more acceptable, because the connection between payments and services can be more sensible. According to Tiebout model, individuals are like customers when they decide about to which self-government's area they should move on the basis of "programs" (Tiebout, 1956). In this sense, the local tax payer votes with their feet. It makes it possible to produce local utilities efficiently, because tax payers decide about secured public utilities on the basis of local taxes, like customers decide what to buy, considering the market price. As long as taxes are in harmony with marginal cost - which means the extension of local services for new settlers - the result will be optimal in Pareto sense like in the case of the private sector. As an example, local entrepreneurship tax offered to companies by the self-government can inspire developments and local services.

Tax amnesty should be avoided. According to international experience (e.g. Greece) tax amnesty can decrease tax morale, and if repeated amnesty is expected then willingness of paying taxes may also fall.

Developing the communication of tax authority to improve tax morale. In 1996 IOTA (Intra-European Organisation of Tax Administrations) has been established to support the cooperation of different tax authorities in different countries. 44 national tax offices joined the organization. The office of IOTA is in Hungary, Budapest ${ }^{17}$. With the help of this organization, the practice of national communication techniques is shared, as well as the fair administration and the experience of teaching students about taxation.

According to the results of a research made by the British tax authority, every authority after understanding the mechanism of tax payers' behaviour should have the possibility to change parameters of the tax-system to inspire tax payers to pay their tax more properly. As a result of this research the tax gap was decreased by the help of information about tax payers. The methods are the following:

- decreasing administrative limits and simplifying the processes at those tax payers who fulfilled their payment duties

${ }^{17}$ Intra-European Organisation of Tax Administrations (2008): IOTA Strategy 20082012 (IOTA, Slovenia) http://www.iota-tax.org/images/stories/documents/statutory _documen ts/strategy_2008-2012.pdf 
- making preventive advices and developing education at those tax payers who fulfilled their payment duties only partly

- carrying out proportional penalties at those tax payers who violated their payment duties ${ }^{18}$.

\section{Methodology of the Research}

Due to these negative socio-economic conditions I decided to observe the willingness of tax paying of individuals, and their knowledge about the share of self-governments from the state tax income as well as their opinion about those immoral behaviour which are against the taxation rules. In order to test I used a survey questionnaire which can be found in the annex of the paper.

The questionnaire was filled by 95 respondents, mostly part-time students taking part in adult education at the Budapest Business School and some employees of BBS.

The dependent variable was the individual level of tax morale and the explanatory variables were demographic variables, personality characteristics, commitment to local self-governments, willingness of taking different levels of risk, etc. The used statistical methods for testing the relations between the variables were the following: multivariate correlation and regression, analysis of variance, t-tests for testing correlation coefficients. The general level of significance is $5 \%$, unless it is stated otherwise.

\section{Empirical Results}

Out of the 95 participants, 75 answered that there existed shared state taxes. According to them, the local self-governments receive on average $29 \%$ of the total vehicle tax while this ratio is much lower, only $10.82 \%$ on average in case of PIT. (Note, that the right answer was $40 \%$ in case of vehicle tax and $0 \%$ in case of PIT.) However, it is noteworthy that the standard deviation of the answers is rather large either in the case of vehicle tax or in the case of PIT: 31.75 and 17.55 percentage point, respectively (which means that the coefficient of variation is above $100 \%$ in both cases, meaning that the answers are quite heterogeneous). Generally, we can say that respondents are not really aware of the right share of state taxes, but they mostly consider lower shares of the total tax revenue of the state. However there

\footnotetext{
${ }^{18}$ http://elib.kkf.hu/edip/D_15441.pdf
} 
are a few exemptions as well (e.g. there were also responders who believed that $100 \%$ of the vehicle tax and PIT is received by local selfgovernments).

Not only the measure of shared state taxes are not clear to most of the respondents, but even the 20 cases out of the 95 who answered that there were no shared state taxes in Hungary at all can be considered as many. My assumption was that adult students of economics (not freshmen) who are 30 years old, on average, know the fact that either the vehicle tax or the PIT are shared state taxes which form the income of tax systems both on the state and the local level. This significant ignorance may cause the high level of variation in the answers concerning the shares of local governments from the mentioned two state taxes.

It is important to emphasise that exactly half of the respondents would accept even higher tax rate if they were sure that the surplus above the official tax rate is the exclusive revenue of the local self-government. As it is visible in Table 1, males have significantly higher willingness to accept higher tax burden for this reason. Compared to the current 16\% PIT rate, males would accept even more than two percentage point higher tax rate in order to help the functions of the local self-governments. In case of females this extra tax burden is almost one percentage point lower on average which difference between the two gender is significant $(\mathrm{F}=5.31 ; \mathrm{p}=0.023)$.

Table 1. Willingness of paying extra tax burden (percentage point)

\begin{tabular}{lcc}
\hline \multicolumn{1}{c}{ Gender } & Mean & St.dev. \\
\hline Male & 2.13 & 2.55 \\
Female & 1.16 & 1.55 \\
\hline
\end{tabular}

Source: own calculation.

It is generally accepted that payments in connection with local services are typically more accepted since the relation between the payment and the service is more appreciable (Tiebout, 1956). According to this model, the individuals appear as consumers who decide to which local selfgovernment they move basing on the possibilities they have to offer. In the view of Tiebout, it makes possible to efficiently produce local public goods since the customers choose from the public goods provided by the local 
communities based on the level of local taxes similarly to the choice of the customers in the market based on the prices of products ${ }^{19}$.

As a result, inhabitants and enterprises with the same preferences will be concentrated in the same district. The theory of Tiebout resulted in several models of efficient inter-governmental race for mobile resources of economy.

Table 2 contains the correlation matrix of the observed variables. Those correlation coefficients which are significant at the $5 \%$ level are marked by bold. In the following the most important ones, which are interesting for the research topic, are discussed.

It seems that men support the finance issues of local self-governments more than females, since they are not only willing to pay higher tax burden in order to increase local revenues, but they assume that self-governments receive higher shares from vehicle tax and PIT. However, this is only an assumption at their side, which is possibly a higher share than the actual real rate, which is noteworthy. I do not consider it as a systematic failure of overestimation by males. In connection with the males' willingness of paying higher tax burden, I think it shows rather the pursuit that males support more the delegation of the use of public resources at the local level.

Responders were asked to imagine the situation that the general PIT burden is $30 \%$ and they have realised 1 million HUF income for an extra work which is similar to their general occupation but not part of their job. They have the possibility to buy a fictive invoice of half million HUF which can be considered as cost and this way it reduces the income to its half. The question was, how many percent of the nominal value of the invoice are they willing to pay in case of different risk levels of being caught. The answer at $0 \%$ of risk is considered as the individual level of tax morale. The possible maximum for this question is $30 \%$, since it would be totally against the rational decision making if anyone paid more than $30 \%$ of the nominal value of the invoice in case of $30 \%$ tax burden. If someone is willing to pay the total tax burden (30\%) to a third party instead of the state then his/her tax morale is considered as zero $(0 \%)$. If someone refuses to pay anything for a fictive invoice even in a riskless option then his/her tax morale is considered as full $(100 \%)$. So the answers for the riskless option (between 0 and 30\%) were transformed to a scale between 100 and $0 \%$.

${ }^{19}$ As long as the payable taxes are in line with the marginal cost of expanding the local services to a newcomer, the result can be considered as Pareto optimal like in the case of private sector. For example the local business tax may support those developments and local services which are offered to entrepreneurs by the self-governments. 
Table 2. Correlation matrix of the examined variables

\begin{tabular}{|c|c|c|c|c|c|c|c|c|}
\hline & \multicolumn{2}{|c|}{ Jocal self-gov. share } & \multirow{2}{*}{$\begin{array}{l}\text { Extra tax } \\
\text { burden for } \\
\text { self-gov. }\end{array}$} & \multicolumn{4}{|c|}{ Pay for fictive inv. if the risk is } & \multirow{2}{*}{$\begin{array}{l}\text { Mach. } \\
\text { score }\end{array}$} \\
\hline & $\begin{array}{c}\text { from } \\
\text { vehicle tax }\end{array}$ & $\begin{array}{c}\text { from } \\
\text { PIT }\end{array}$ & & $0 \%$ & $25 \%$ & $50 \%$ & $75 \%$ & \\
\hline $\begin{array}{l}\text { Share from } \\
\text { vehicle tax } \\
\text { Share from }\end{array}$ & 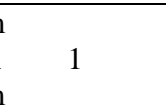 & & & & & & & \\
\hline PIT & 0.2382 & 1 & & & & & & \\
\hline $\begin{array}{l}\text { Extra tax } \\
\text { burden } \\
\text { Fictive inv }\end{array}$ & -0.1016 & -0.0368 & 1 & & & & & \\
\hline (risk: $0 \%$ ) & -0.1875 & 0.0374 & -0.0601 & 1 & & & & \\
\hline $\begin{array}{l}\text { Fictive inv. } \\
\text { (risk: } 25 \% \text { ) } \\
\text { Fictive inv. }\end{array}$ & -0.1402 & 0.0230 & -0.0326 & 0.6209 & 1 & & & \\
\hline $\begin{array}{l}\text { Fictive inv. } \\
\text { (risk: } 50 \% \text { ) } \\
\text { Fictive inv. }\end{array}$ & -0.0765 & 0.0203 & 0.0415 & 0.2900 & 0.6214 & 1 & & \\
\hline $\begin{array}{l}\text { Fictive inv. } \\
\text { (risk: 75\%) } \\
\text { Mach }\end{array}$ & -0.0043 & -0.0701 & 0.0084 & 0.1648 & 0.4485 & 0.8010 & 1 & \\
\hline score & 0.0431 & 0.0586 & 0.0750 & 0.3462 & 0.2215 & 0.1685 & -0.0024 & 1 \\
\hline Gender & 0.2023 & 0.3042 & 0.2325 & 0.1590 & 0.1633 & 0.1724 & 0.1899 & 0.144 \\
\hline Age & 0.0495 & 0.0241 & -0.1153 & -0.2458 & -0.1510 & -0.2339 & -0.1657 & -0.273 \\
\hline
\end{tabular}

Source: own calculation.

Maybe it is surprising that $29.5 \%$ of the responders would pay even the total tax burden for a fictive invoice instead of paying it to the state budget... Even if there is no risk of being caught it must be clear for all that this behaviour is immoral and causes damages for the society.

As it was expected there is direct relationship between the level of Machiavellian personality and the maximum amount paid for a fictive invoice in a riskless option $(\mathrm{r}=0.346)$. It can be explained by two reasons: on the one hand it is not a dilemma to reach individual gain at the expense of the society for people with strongly Machiavellian personality, while on the other hand these people consider the state leaders typically as opportunistic and self-serving persons, which may justify their behaviour of decreasing the tax revenues.

There is a less than intermediate strength, indirect relationship between the age of responders and the maximum amount paid for a fictive invoice in a riskless option $(r=-0.246)$. Anyway, it has to be emphasised that it does not mean at all an increasing tax morale as time passes. This research compared the answers of people as cross-sectional data and it shows that the tax morale of older people is significantly higher at the date of observation. 
Obviously it does not mean that the tax morale of the younger people will be better as they get older. The appalling thing is that after several years, as the older people of now will retire and get out of the sphere of active tax payers, their place will be taken by this younger generation with its lower tax morale. All in all, the current situation does not support the increase of tax morale in the next years. In my opinion some important steps are necessary to reverse this negative tendency concerning the tax morale of the younger generation. Without a successful intervention of the state, the tax morale will not get better (e.g. "I was not caught so far, why should I pay in the future?") and what is worse, this rather negative tax morale will be the example for the next generations.

The maximum amounts paid for a fictive invoice in case of different levels of risk are not independent of each other. Obviously, only those people will pay for a fictive invoice in a risky option who would do this also in a riskless option, however vice-versa it is not necessarily true. It can be seen in Table 2 that strong relationships are only between the low risk options and between the high risk options. There is a more than intermediate strength direct relationship between the maximum amounts in case of the riskless and low risk options $(\mathrm{r}=0.621)$, while there is a strong direct relationship between the maximum amounts in case of the high risk options $(r=0.801)$. Naturally, the risk of being caught influences negatively the maximum amount paid for a fictive invoice which can be observed in Table 3.

In case of no risk the responders are willing to pay on average even the half of the tax burden for a fictive invoice. If the risk is $25 \%$ then this amount decreases to its half. As the risk increases the amount decreases exponentially. This indirect relationship is strong and significant even below the $1 \%$ level $(\mathrm{F}=48.56 ; \mathrm{p}=0.0000)$.

Table 3. Relation between the risk of caught and tax morale (percentage point)

\begin{tabular}{lcc}
\hline \multicolumn{1}{c}{ Risk level } & Mean & St. dev. \\
\hline Fictive invoice (risk: 0\%) & 15.07 & 12.47 \\
Fictive invoice (risk: 25\%) & 7.03 & 9.44 \\
Fictive invoice (risk: 50\%) & 2.80 & 5.71 \\
Fictive invoice (risk: 75\%) & 1.33 & 4.57 \\
\hline
\end{tabular}

Source: own calculation 
Figure 2. The maximum ratio of the nominal value paid for a fictive invoice in case of different levels of risk

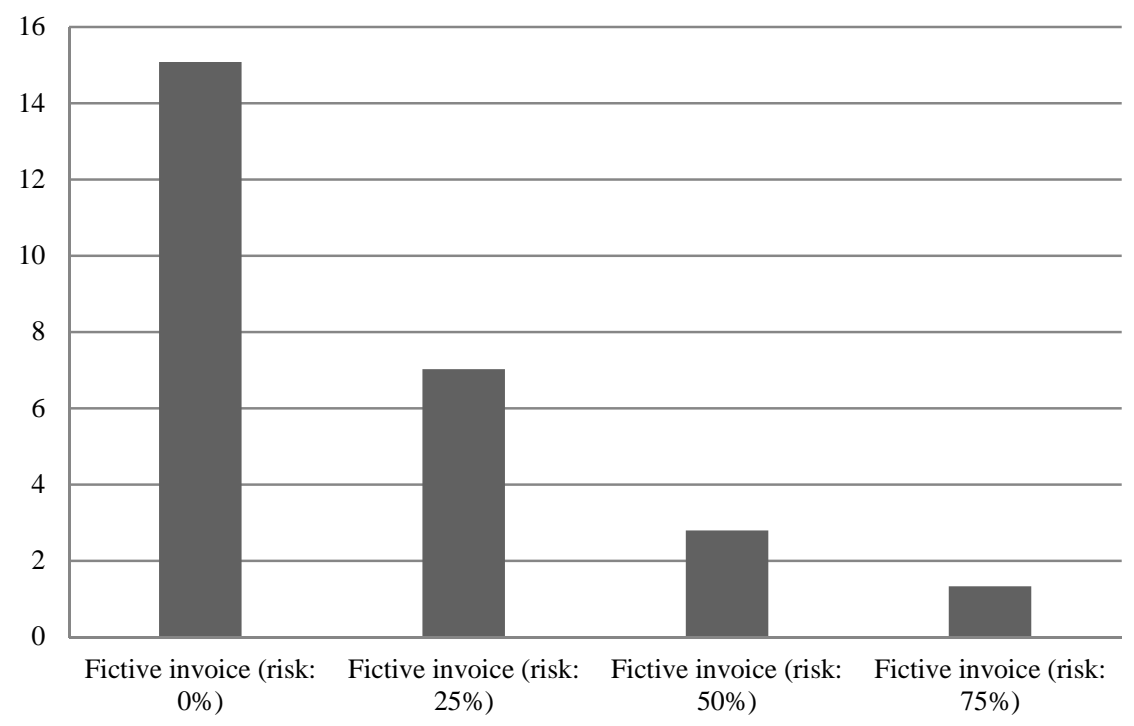

Source: own calculation.

Even though the sample is not representative, it is visible that in case of no or minimal supervision the fictive invoice is a real option to reduce the tax base for those who have some extra income. However the willingness for this kind of manipulation intensively decreases if the risk level reaches at least $50 \%$. Considering that there are no exact data for the tax payers about the real risks, these are more-or-less some kind of subjective probabilities, there is a good possibility to reduce tax evasion by strengthening the general belief about the efficiency of supervision and the higher and higher risk of being caught.

The Hungarian National Tax and Customs Administration (NTCA) has introduced a more efficient and more powerful supervision system after its organisational transformation in 2011. In 2012 there were 2029 supervision processes concerning private asset growth which is almost double than in 2011. Out of the 2029 supervisions 1578 (78\%) finished with a sanction, resulting altogether 20.6 billion HUF tax difference that is $89 \%$ higher than in the previous year. I do not believe that tax morale can be strengthened only by increasing the number of supervision processes or by increasing the level of tax fines, however it may have enough restrictive power for tax 
payers with "vacillating" tax morale in case of significant risk of being caught.

The regression coefficients of those explanatory variables which are in the closest relation with the tax morale can be seen in Table 4.

Table 4. Explanatory variables of tax morale

\begin{tabular}{lrrrr}
\hline Coefficients & $b_{i}$ & $s\left(b_{i}\right)$ & $t$-value & $p$-value \\
\hline Constant & 56.974 & 20.443 & 2.787 & 0.006 \\
Mach score & -0.775 & 0.274 & -2.830 & 0.006 \\
Gender & -9.273 & 8.175 & -1.134 & 0.260 \\
Age & 0.804 & 0.494 & 1.627 & 0.107 \\
\hline
\end{tabular}

Source: own calculation.

The Mach score of the responder influences indirectly and most significantly the individual tax morale. Both variables are measured on a scale between 0 and 100. In case of 1 point higher Mach score (more Machiavellian personality) the tax morale is on average 0.78 points lower according to the regression, which effect is significant below the $1 \%$ level $(\mathrm{p}=0.006)$. It is easy to realise how strong and deteriorative is this effect: compared to a generally well-meaning person (let's suppose a low Mach score of 20) a person with more or less Machiavellian personality (a Mach score of 70 is not rare) has on average cca. 40 points lower tax morale.

Generally speaking the tax morale of males is a little lower than females, however the effect of gender is not significant $(\mathrm{p}=0.26)$.

In case of the effect of age, we can repeat that the tax morale of older generations is currently significantly better than of the younger generations (a one year older responder's tax morale is on average 0.8 points higher), which effect is significant at the $10 \%$ level.

The multiple coefficient of correlation for the total regression function is $\mathrm{R}=0.4 \quad \mathrm{~F}=5.63 ; \mathrm{p}=0.0014)$. So we can conclude that the exploration of some further influencing factors is necessary, however the Mach score is a significant determinant of tax morale and possibly the generation effect is also important. 


\section{Conclusions}

One goal of my study was to create a structure to help defining tax morale which is a complex phenomenon, examined by the tools of law, economy, sociology and psychology. In my paper I have analysed the Hungarian tax morale in connection with personal aspects, the taxation of the socialism and the period after the regime change.

We have seen by the help of some historical examples and some actual macroeconomic data that the level of tax morale is quite low in EasternCentral European countries like Hungary. Based on a questionnaire survey answered by 95 Hungarian people this fact is supported and we observed the main reasons and motivations of this low tax morale.

The questionnaire was filled by 95 persons, mostly part-time students taking part in adult education at the Budapest Business School and some employees of BBS.

Out of the 95 participants 75 answered that there exist shared state taxes. Generally we can say that respondents are not really aware of the right share of state taxes but they mostly consider lower shares of the total tax revenue of the state, however there are a few exemptions as well.

Not only the measure of shared state taxes are not clear for most of the responders but even the 20 cases out of the 95 can be considered as too lot who answered that there are no shared state taxes in Hungary at all. My assumption was that adult students of economics who are 30 years old on average know the fact that either the vehicle tax or the PIT are shared state taxes which form the income of tax systems both on state and local level. Maybe a less complicated, more transparent and easier to understand tax rules would be able to strengthen the willingness to pay taxes properly.

It seems that men support the finance issues of local self-governments more than females, since they are not only willing to pay higher tax burden in order to increase local revenues but they assume that self-governments receive higher shares from vehicle tax and PIT. In connection with the males' willingness of paying higher tax burden, I think it shows rather the pursuit that males support more the delegation of the use of public resources at the local level.

There is a less than intermediate strength, indirect relationship between the age of responders and the maximum amount paid for a fictive invoice in a riskless option. Anyway, it has to be emphasised that it does not mean at all an increasing tax morale as time passes. This research compared the answers of people as cross-sectional data and it shows that the tax morale of older people is significantly higher at the date of observation. All in all, the current situation does not support the increase of tax morale in the next 
years. In my opinion some important steps are necessary to reverse this negative tendency concerning the tax morale of the younger generation.

Concerning the personal characteristics, Machiavellian personality shows indirect relation with willingness of taxpaying. The Mach score of the responder influences indirectly and most significantly the individual tax morale. Both variables are measured on a scale between 0 and 100. In case of 1 point higher Mach score (more Machiavellian personality) the tax morale is on average 0.78 points lower according to the regression.

Naturally this survey was not representative, however it is still able to show which points of the system are to be changed urgently. A less complex but more proportional tax system which is easier to understand for most people, with a more transparent and effective redistribution of collected taxes, besides an efficient tax control could significantly increase the general level of tax morale.

\section{References}

Allingham, M., \& Sandmo, A. (1972). Income tax evasion: A theoretical analysis. Journal of Public Economics, 1(3-4). http://dx.doi.org/10.1016/00472727(72)90010-2.

Andreoni, J., Erard, B., \& Feinstein, J. (1998). Tax Compliance. Journal of Economic Literature, 36.

Frey, B. S., \& Weck-Hannemann, H. (1984). The Hidden Economy as an 'Unobserved' Variable. European Economic Review, 26(1-2). http://dx.doi.org/10.1016/0014-2921(84)90020-5.

Gray, C. W. (1990). Tax systems in the reforming socialist economies of Europe. PRE Working Paper Series, WPS 501, The World Bank, Washington, p. 19. http://dx.doi.org/10.1080/14631379108427668.

Keen, M., Kim, Y., \& Varsano, M. (2006). The 'Flat Tax(es)': Principles and Evidence. IMF working paper No. 06/218.

Kornai, J. (1990). The road to a free economy - shifting from a socialist system the example of Hungary. New York: W.W. Norton \& Company.

Kornai, J. (1996). Négy jellegzetesség, A magyar fejlődés politikai gazdaságtani megközelítésben. 2. rész, Közgazdasági Szemle, 53(1).

Kovácsné Sipos, Á. \& Tóth, Zs. (2015). Tax morale - Hungarian legal, historical, social and cultural circumstances. Kolozsvár. In press.

Krekó, J. \& Kiss, G. (2007). Adóelkerülés és a magyar adórendszer. MNBtanulmányok sorozat 65. szám ISSN 1787-529. Retrieved form: http://www.mnb.hu/Root/Dokumentumtar/MNB_/Kiadvanyok/mnbhu_mnbtanu lmanyok/MT_65.pdf (5.11.2014).

Lackó, M. (2006). Az adóráták és a korrupció hatásai a munkapiacra - Keresztmetszeti összehasonlító elemzés az OECD-országokon. Közgazdasági Szemle, november 
La Porta, R., Lopez de Silanes, F., Shleifer, A., \& Vishny, R. (1999).The Quality of Government. Journal of Law, Economics and Organization, 15(1). http://dx.doi.org/10.1093/jleo/15.1.222.

Méder, Zs. Z., \& Simonovits, A., \& Vincze, J. (2012). Adómorál és adócsalás társadalmi preferenciák és korlátozott racionalitás. Közgazdasági Szemle, október.

Musgrave, R. \& Musgrave, P. (1989). Public Finance in Theory and Practice. New York: McGraw-Hill Book Company.

Nagy, A. (2004). Helyi adózás Magyarországon. Debreceni jogi műhely. Retrieved form http://www.debrecenijogimuhely.hu/archivum/otdk_kulonszam/helyi adozas_magyarorszagon/ (12/02/2015),

OECD (2004). Employment Outlook.

OECD (2012). Economic Surveys Hungary.

Sharle, Á. (2002). Tax evasion as innovation in small businesses in Hungary. manuscript.

Schneider, F. (2005). Shadow Economies of 145 Countries all over the World: Estimation Results over the Period 1999 to 2003. Retrieved form: http://ftp.iza.org/dp1431.pdf (05.03.2015).

Simonovits, A. (2010). Adómorál és adórendszer. Közgazdasági Szemle. június.

Tanzi, V. (1991). Tax reform and the move to a market economy: overview of the issues. The role of tax reform in Central and Eastern European economies.- Organisation for Economic Co-operation and Development.

Tanzi, V. (1993). Fiscal policy and the economic restructuring of economies in transition. IMF, Fiscal Affairs Department, WP/93/22.

Tanzi, V. (2002). Corruption Around the World: Causes, Consequences, Scope, and Cures. In G. T. Abed \& S. Gupta (Eds.). Governance, Corruption and Economic Performance. Washington: International Monetary Fund.

Tóth, E. (2010). Az APEH marketingkommunikációja, az adómorál javítása BGFKKF. Retrieved form http://elib.kkf.hu/edip/D_15441.pdf (11.11.2014).

Turay, A. (2000). Az ember és az erkölcs. Alapvető etika Aquinói Tamás nyomán. Retrieved form:http://mek.oszk.hu/08700/08783/html/etika.htm (11.02.2015).

Vigvari, A. (2002). Az önkormányzati pénzügyek közgazdaságtanának néhány alapkérdése. Pénzüigyi Szemle, 2.

Yitzhaki, S. (1974). Income Tax Evasion: A Theoretical Analysis. A Note. Journal of Public Economics, 3. http://dx.doi.org/10.1016/0047-2727(74)90037-1.

1990. évi CIV. törvény a Magyar Köztársaság 1991. évi állami költségvetéséről és az államháztartás vitelének 1991. évi szabályairól (Act CIV of 1990 on the State Budget of Hungary)

1996. évi CXXIV. törvény a Magyar Köztársaság 1997. évi költségvetéséről (Act CXXIV of 1996 on the State Budget of Hungary)

8/2010. (I.28.) számú AB határozat (Decree 8 of 2010 of the Hungarian Constitutional Court) 


\section{8 Ágnes Sipos}

Intra-European Organisation of Tax Administrations (2008.). IOTA Strategy 20082012 (IOTA, Slovenia) http://www.iota-tax.org/images/stories/documents/ statutory_documents/strategy_2008-2012.pdf.

http://vallalkozoi.negyed.hu/vnegyed/20130903-romokban-az-adomoral.html $(05 / 09 / 2013)$. 


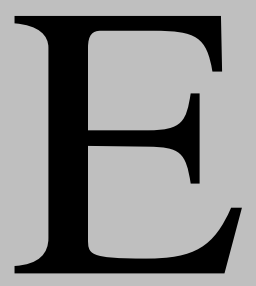

Q U I L I B R I U M

Quarterly Journal of Economics and Economic Policy

\section{International Economics: Determinants of Trade and Capital Flows}


